\title{
Innovasjon i norsk offentlig sektor - dilemmaer og utfordringer
}

\section{Introduksjon til særnummer af Samfundslederskab i Skandinavien} Av Ann Karin Tennås Holmen, Catharina Bjørquist og Ulla Higdem *)

Offentlig sektor i Norge har de siste 10-15 år opplevd et økende krav og forventning om innovasjon. Innovasjon har blitt et begrep som symbolsk har blitt oppfattet som noe positivt, som vi gjerne vil stimulere til og som danner grunnlag for verdiskapning og vekst. Innovasjonsbegrepet har også dannet grunnlag for en økende søken etter nye praktiske løsninger, som skal forbedre tjenester og prosesser. Kravet og forventningene kommer gjennom nasjonale policy dokumenter, forskning, gjennom erfaringer fra andre land, men også fra offentlige organisasjoner. I kjølvannet av dette er det iverksatt en rekke prosjekter, endringsprosesser og utviklingsarbeid under tittelen «Innovasjon» i kommuner, fylkeskommuner, statlige organisasjoner og andre offentlige organisasjoner. Det er med andre ord en forventning om, at offentlige organisasjoner skal arbeide for innovasjon og innovere. Vi spør, hvilken bakside kan dette arbeidet ha?

*) Ann Karin Tennås Holmen, PhD statsvitenskap, førsteamanuensis, Universitetet i Stavanger; Catharina Bjørkquist, PhD statsvitenskap, førsteamanuensis, Høgskolen i Østfold; Ulla Higdem, Dr.scient, professor, Høgskolen i Innlandet 
Forståelsen av innovasjon i offentlig sektor er annerledes enn for privat sektor. For privat sektor er gjerne innovasjon forstått som nye produkter eller tjenester, som selges til kunder i et marked, og hvor lakmustesten på om det er en innovasjon (til forskjell fra en oppfinnelse) er, om varen eller tjenesten blir produsert og solgt i dette markedet (Hartley, 2008; Hartley, Sørensen, \& Torfing, 2013). Selv om flere land har gått langt i å markedsgjøre offentlige tjenester, vil innovasjoner i prinsippet ikke nødvendigvis avhenge av et markeds godgjøring av en innovasjon. Snarere er det en forståelse av, hva som er av offentlig verdi (public value), eller av verdi for samfunnet, borgere og brukere. De, som mottar, bruker eller får tjenester eller produkter fra offentlig sektor, er borgere, brukere og samprodusenter (Osborne, Radnor. \& Strokosch, 2016) snarere enn kunder, og hvor det i stor grad er borgernes skattepenger, som finansierer sektoren. Derfor kan det også oppstå innovasjoner som er til gode for noen, men ikke for alle, og innovasjoner som kan gå galt. Innovasjon i offentlig sektor er ikke avgrenset til tjenester, men kan også dreie seg om prosesser, organisasjoner og ikke minst politikkutforming og styringsformer (Moore, 2008; Crosby, 't Hart, \& Torfing, 2017).

Dette spesialnummeret presenterer tre ulike innblikk i konsekvenser og dilemmaer av innovasjonstrykket på offentlig sektor i norsk kontekst. Det er valgt å sette et kritisk blikk på innovasjon og uønskede konsekvenser i møtet med offentlige organisasjoner, noe som er mindre belyst i litteraturen. Spesielt interessant er debatten rundt interaktive og samskapte innovasjonsprosesser og utfordringer og dilemmaer som oppstår. Det er likevel viktig å presisere at innovasjonsarbeidet som pågår i norsk offentlig sektor også bidrar til positive effekter og at samskaping er en viktig driver i offentlig innovasjonsarbeid.

\section{Offentlig innovasjon på norsk dagsorden}

I 2011 ble en nasjonal utredning (NOU 2011:11) om «Innovasjon i omsorg» lagt fram. Dette var starten på en ny oppfatning om offentlig sektor som en selvstendig aktør for tjenesteinnovasjon, og ikke bare som tilrettelegger for innovasjon i privat sektor. Det var spesielt kommunene, som dette innovasjonsfokuset ble rettet mot og da spesielt helsesektoren som opplevde store utfordringer. Norske kommuner er primærprodusent av offentlige tjenester. Helse- og omsorgstjenester utgjør den største utgiftsposten i kommunale budsjetter, og behovet for endring var noe kommunene også selv hadde følt på pulsen i lang tid. Selv om innovasjonsbegrepet ble oppfattet som fremmed for helsesektoren, fikk utredningen gradvis legitimitet og kan betraktes som en viktig kilde til den oppmerksomheten innovasjon etter hvert har fått i kommunene. I etterkant har stadig flere deler av norsk offentlig sektor møtt tilsvarende trykk gjennom nye meldinger, og ikke minst forskning på og om offentlig sektor. Et økende omfang av forskningsprogrammer legger til rette for innovasjonsprosjekter, hvor offentlige organisasjoner arbeider sammen med forskningsmiljøer for å fremme innovasjon. I 2018 ble fokuset på innovasjon i kommuner og offentlig sektor ytterligere trappet opp. Den sittende regjering varslet et 
innovasjonsløft i offentlig sektor og startet arbeidet med stortingsmeldingen om innovasjon i offentlig sektor. Meldingen skal foreligge i 2020. Kommunenes organisasjon (KS) lanserte i februar 2018 det såkalte Innovasjonsbarometeret, som måler innovasjon i kommunal sektor. Barometeret er sterkt inspirert av tilsvarende undersøkelse i Danmark, som første gang ble lansert i 2015. Innovasjonsbarometeret utviklet i Norge, har spesielt fokus på helse- og omsorgssektoren samt oppvekst- og utdanningssektoren. Her undersøkes det om og hvordan kommunene innoverer, hvordan kommunene arbeider med innovasjon samt drivere og hemmere det finnes for innovasjon (resultater fra innovasjonsbarometeret 2018 KS). Som en respons på det økende innovasjonstrykket, er det etablert et tverrfaglig forskernettverk for relatert til offentlig innovasjon. Nettverket ble etablert i 2018 og har navnet INNOFF (https://www.innoff.no/).

Dagens situasjon forteller oss, at innovasjonstrykket på offentlig sektor på ingen måte vil avta i de kommende år. Vi beveger oss dermed i retning av et styringsparadigme som preges av at innovasjon er en av de mest sentrale drivere for utvikling av offentlig sektor. Innovasjon blir utelukkende omtalt som noe positivt, noe offentlig sektor ønsker, og skal arbeide for å vise resultater fra. Innovasjon skal settes på dagsorden, læres, utvikles, tilpasses og bli en del av offentlig sektors hverdag. Som et resultat av dette, vil offentlige organisasjoner ha behov for å utvikle nye roller, verktøy, organisatoriske løsninger og strategier for å utvikle et handlingsrom for innovasjon. Det er lite forskning på innovasjoners og innovasjonsprosessers uønskede konsekvenser. Det er i lys av dette at det er grunn til å spørre hvor den kritiske røsten til utviklingstakten befinner seg. Har et slikt fremvoksende fokus på innovasjon også sine baksider?

Dette spesialnummeret av tidsskriftet Samfundslederskap i Skandinavien, fokuserer på mulige utfordringer ved det økende innovasjonstrykket som offentlig sektor utsettes for. De tre bidragene viser ulike sider av dette utfordringsbildet og representerer derfor en bredde av den forskningen som pågår i Norge.

Charlotte Sørensen og Ailin Aastvedts artikkel Loering av feilslåtte innovasjoner setter fokus på, at det først er i ettertid vi kan vite om en innovasjon blir vellykket eller mislykket. Formålet med artikkelen er å vise at innovasjon er en prosess og ikke kun et vellykket resultat eller en fruktbar ideologi. Ved å belyse en feilslått innovasjon viser de at vi har vel så mye å lære av feilslåtte innovasjoner som av vellykkede. Forfatterne illustrerer dette gjennom «Terra-saken», som et eksempel på en feilslått innovasjon. «Terra-saken» er velkjent i norsk sammenheng, hvor åtte norske kommuner utfordret lovverket på en kreativ måte for å kunne låne penger til finansielle plasseringer. Det endte med store negative konsekvenser for disse kommunenes økonomiske situasjon og tjenestetilbud. «Terra-saken» var et resultat av en oppfordring fra sentrale myndigheter samtidig som finansproduktene, som ble presentert, representerte nye og moderne produkter i kommunenes finansforvaltning. I dag er innovasjon et slikt magisk og forførende begrep, som 
myndighetene mener skal løse alle samfunnets utfordringer. Artikkelen viser hvordan myndighetenes ønske om å skape mer innovasjon kan også få negative konsekvenser.

Kristiane Marie Lindlands artikkel Når middelet vanhelliger målet - motstridende budskap $i$ implementering av medarbeiderdrevet innovasjon i offentlig sektor, retter oppmerksomheten mot medarbeiderdrevet innovasjon (MDI) som organisasjonskonsept, som kan føre til paradoksale forståelser i implementeringen. strategi for tjenesteutvikling i offentlig sektor. Forfatteren viser til en spenning mellom MDI som konsept og fortolkningen av denne i implementeringen. MDI kan i offentlig sektors kontekst forstås som en forholdsvis radikal innovasjonsform, der medarbeidere initierer og driver frem nye løsninger ut fra behov, de selv identifiserer. Denne innovasjonsformen impliserer at medarbeidere har en stor grad av handlingsrom i selv å vurdere behovet for alternative løsninger, tilgjengelige ressurser og mandat til å initiere og gjennomføre endringer. MDI bryter dermed med New Public Managements (NPMs) fokus på prosedyrer, optimalisering og kontroll. Men hva skjer når kjerneideen står i kontrast til organisasjonen den skal implementeres inn i? Artikkelen bidrar til økt forståelse av hvordan innovasjon kan påvirkes av implementeringsprosessen. Funnene indikerer at mange av de grepene som ble tatt for å implementere MDI, faktisk kunne virke kontraproduktivt på målet om å fostre MDI.

Gro Anita Homme, Roger Normann, Ivan Puga-Gonzalez og F. LeRon Shults' artikkel Multi-agent kunstig intelligens og offentlig politikk, tar for seg sosiale simuleringsmodeller som virkemiddel for politikkutvikling, evaluering og planlegging. Forfatterne diskuterer muligheter og begrensninger ved sosial simulering og ulike typer modeller samt etiske problemstillinger. Brukerne av modellen involveres i utviklingsprosessen for å sikre forståelse for modellen, og hvilken anvendelse den har. Sosial modeller har vært brukt til å simulere blant annet tiltak i folkehelsearbeid, årsaker og konsekvenser av kulturelle konflikter og ideologisk polarisering. Forfatterne argumenterer for at bruken av modellering kan være et viktig bidrag med hensyn til å forstå interaksjon mellom faktorer på ulike nivåer og gi innsikt i komplekse sosiale systemer. Samtidig er det en utfordring med å forstå mekanismer, som for eksempel virker inn på menneskers handlefrihet eller geografiske rammer, og hvordan dette påvirker ulike policy-scenarier. De etiske utfordringene som reises, er blant annet at modellene vil kunne brukes til å manipulere befolkningen til å handle på bestemte måter. Hvilket reiser spørsmål om hvem som skal ha tilgang og dermed bidra til å definere termer og få sine antakelser synliggjort i prosessen. 


\section{Referanser}

Crosby, B., 't Hart, P., \& Torfing, J. (2017). Public Value Creation through Collaborative Innovation Public Management Review, 19(5). $\quad$ https://doi.org/10.1080/14719037.2016.1192165

Hartley, J. (2008). The Innovation landscape for public service organizations. In J. Hartley (Ed.), Managing to improve public services. Cambridge: Cambridge University Press.

Hartley, J., Sørensen, E., \& Torfing, J. (2013). Collaborative Innovation: A Viable Alternative to Market Competition and Organizational Entreprenesurship. Public Administration Review., 73(6), 821-830. https://doi.org/10.1111/puar.12136

Moore, M., \& Hartley, J. (2008). Innovations in governance. Public Management Review, 10(1), 3-20.

NOU 2011:11. (2011). Innovasjon i omsorg. Oslo: Helse- og omsorgsdepartementet.

Osborne, S. P., Radnor, Z. \& Strokosch, K. (2016) Co-Production and the Co-Creation of Value in Public Services: A suitable case for treatment?, Public Management Review, 18:5, 639-653. https://doi.org/10.1080/14719037.2015.1111927 